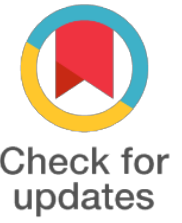

*For correspondence:

pvphuc@hcmus.edu.vn

Competing interests: The authors declare that no competing interests exist.

Received: 2017-08-06 Accepted: 2017-08-17

Published: 2017-09-05

Copyright The Author(s) 2017. This article is published with open access by BioMedPress (BMP).

This article is distributed under the terms of the Creative Commons Attribution License (CC-BY 4.0) which permits any use, distribution, and reproduction in any medium, provided the original author(s) and the source are credited.

\section{Adipose-derived stem cells alleviate glucose tolerance in type 2 diabetic mouse}

\author{
Anh Bui Nguyen-Tu, Cong Le-Thanh Nguyen, Anh Thi-Minh Nguyen, Nhat \\ Chau Truong, Ngoc Kim Phan, Loan Thi-Tung Dang
}

Laboratory of Stem Cell Research and Application, University of Science, Vietnam National University, Ho Chi Minh City

\section{Abstract}

Background: Type 2 diabetes (T2D) is the most common form of diabetes and accounts for 9o$95 \%$ of all existing diabetic cases. The main etiologies of T2D include insulin resistance in target tissues, insufficient secretion of insulin and subsequent decline of pancreatic $\beta$-cell function. Recently, many studies have suggested that adipose - derived stem cells (ASCs) were potential to alleviate insulin resistance and hyperglycemia and promote the islets repair. In this study, ASCs were hypothesized that they could have ameliorative effects on type 2 diabetic mice.

Methods: Type 2 diabetic mice were induced by a combination of high-fat diet and injection of STZ $100 \mathrm{mg} / \mathrm{kg}$ and NA $120 \mathrm{mg} / \mathrm{kg}$. Thereafter, two doses of 106 human ASCs were transplanted 2 week interval into each mouse via the tail vein. The mice were monitored health condition, rate of mortaity, body weight, consumption of food and water, blood glucose level, serum insulin level and histological structure of pancreatic islets.

Results: Our results indicated that the ASC-treated mice expressed improved condition in comparision with non-treated diabetic mice. The consumption of food and water as well as the blood glucose level decreased. Simultaneously, ASC transplantation improved the impaired glucose tolerance and insulin tolerance in T2D mice. Besides, the total cholesterol have significantly decreased.

Conclusion: it is suggested that human ASCs infusion is safe and effective for type 2 diabetes mellitus in mice regarding the improved glucose metabolism and insulin resistance.

\section{Keywords}

Type 2 diabetes, adipose - derived stem cells, Streptozotocin

Funding

References 